\title{
Lansoprazole is an uncompetitive inhibitor of tissue-nonspecific alkaline phosphatase
}

\author{
Mélanie Delomenède, René Buchet ${ }^{\varpi}$ and Saïda Mebarek \\ Université de Lyon, INSA de Lyon, CPE Lyon, CNRS UMR 5246 ICBMS, Lyon, Villeurbanne Cedex, France
}

Received: 19 February, 2009; revised: 04 May, 2009; accepted: 10 June, 2009

available on-line: 18 June, 2009

\begin{abstract}
Lansoprazole, a known $\mathrm{H}^{+} / \mathrm{K}^{+}$-ATPase inhibitor, is currently used as a therapeutical option for the initial treatment of gastroesophageal reflux disease. Recently, lansoprazole has been found to be an inhibitor of cytosolic PHOSPHO1 (a phosphatase which hydrolyses phosphocholine and phosphoethanolamine), providing a possible therapeutical target to cure pathological mineralization. Since PHOSPHO1 is present inside matrix vesicles, we tested the effect of lansoprazole on matrix vesicles containing several key enzymes for the mineralization process including tissue-nonspecific alkaline phosphatase. We found that lansoprazole can inhibit in an uncompetitive manner tissue-nonspecific alkaline phosphatase. A $K_{\mathrm{i}}$ value of $1.74 \pm 0.12 \mathrm{mM}$ has been determined for the inhibition of tissue-nonspecific alkaline phosphatase by lansoprazole. Lansoprazole, currently used for treating gastroesophageal disease, by inhibiting PHOSPHO1 and tissue-nonspecific alkaline phosphatase could prevent hydroxyapatite-deposition disease and could serve as an adjunct treatment for osteoarthritis.
\end{abstract}

Keywords: alkaline phosphatase, inhibition, lansoprazole, osteoarthritis, PHOSPHO1, phosphocholine

\section{INTRODUCTION}

Lansoprazole is a selective $\mathrm{H}^{+} / \mathrm{K}^{+}$-ATPase inhibitor (Gremse, 2001). Acid suppression with proton pump inhibitors is now the preferred treatment option for the initial treatment of gastroesophageal reflux disease (DeVault \& Castel, 1999; Der, 2003; Kivioja et al., 2004; Shi \& Klotz, 2008). Lansoprazole is used for the short term treatment of erosive reflux oesophagitis, active gastric ulcer, active duodenal ulcer and the treatment of non-steroidal anti-inflammatory drug-induced gastric and duodenal ulcers. It has been also approved for the long-term treatment of healed reflux oesophagitis, healed duodenal ulcer, the treatment of hypersecretory conditions as Zollinger-Ellison syndrome (Gremse, 2001). Lansoprazole, as other substituted 2-pyridylmethylsulfinyl benzimidazoles such as omeprazole, pantoprazole and rabeprazole are weak bases, accumulating inside the acidic environment of $\mathrm{H}^{+} / \mathrm{K}^{+}$-ATPase. At acidic $\mathrm{pH}$ they undergo an acid catalyzed rearrange- ment to a cationic sulfenamide, forming disulfides with cysteines of the $\mathrm{H}^{+} / \mathrm{K}^{+}$-ATPase proton pump (Besancon et al., 1997). Although no use of lansoprazole has been reported to cure bone diseases, it was recently reported that lansoprazole has the ability to modulate in vitro mineralization induced by matrix vesicles (MVs), isolated from calvaria of tissue-nonspecific alkaline phosphatase (TNAP) null mice, by inhibiting PHOSPHO1 (Narisawa et al., 2007). The phosphatase PHOSPHO1 is a soluble enzyme which hydrolyzes specifically phosphoethanolamine and phosphocholine (Pchol) (Roberts et al., 2005) and contributes to increase $P_{\mathrm{i}}$ inside MVs thereby leading to mineralization (Roberts et al., 2006). Osteoblasts and hypertrophic chondrocytes can initiate mineralization by releasing MVs (Anderson, 2007; Kirsch, 2007). MVs are involved in the initial step of mineralization by promoting the formation of hydroxyapatite (HA) inside MVs. Once the crystals have reached a certain size, they rupture the MV membranes and migrate into the extracellular matrix. This is followed by HA

${ }^{\square}$ Corresponding author: René Buchet, Université Lyon 1, UMR CNRS 5246, 43 Boulevard du 11 Novembre 1918,69622 Villeurbanne Cedex, France; tel: 334724313 20; fax: 334724315 43; e-mail: rbuchet@univ-lyon1.fr

Abbreviations: HA, hydroxyapatite; MVs, matrix vesicles; Pchol, phosphocholine; PI-PLC, phosphatidylinositol phosphatase $\mathrm{C}$; $p \mathrm{NPP}, p$-nitrophenylphosphate; $\mathrm{P}_{\mathrm{i}}$, inorganic phospahte; $\mathrm{PP}_{\mathrm{i}}$, inorganic pyrophosphate; TNAP, tissue-nonspecific alkaline phosphatase. 
propagation outside the MVs, supplemented by the $\mathrm{Ca}^{2+}$ and $\mathrm{P}_{\mathrm{i}}$ through circulation, and ultimately HA fills up the space between collagen fibers of the skeletal matrix (Anderson, 2007; Kirsch, 2007). Although $P_{i}$ is continuously supplied by circulation, other sources of $P_{i}$ sustain the mineralization process. One likely source of $\mathrm{P}_{\mathrm{i}}$ could come from the hydrolysis of phosphomonoesters by 5'-AMPase (Einhorn et al., 1985), ATPases (Hsu \& Anderson, 1996; Hsu et al., 1999), PHOSPHO1 (Roberts et al., 2004; 2005; 2007) and tissue-nonspecific alkaline phosphatase (TNAP) (Register et al., 1986; Balcerzak et al. 2003; Anderson et al., 2004). Inhibitors of any phosphomonoesterase enzymes should affect the mineralization process, providing a possible therapeutical target to cure pathological mineralization, such as osteoarthritis, crystal-deposition arthritis, atherosclerosis and tumor calcification (in breast cancer) (Andersen, 2007; Kirsch, 2007). Since PHOSPHO1, is also entrapped in MVs, we tested the effect of lansoprazole on MVs, containing several key enzymes implicated in the mineralization process, including TNAP. We confirmed the therapeutical potential of lansoprazole, as inhibitor of PHOSPHO1 (Roberts et al., 2007) and in addition we found that lansoprazole can also inhibit in an uncompetitive manner TNAP. Therefore the inhibition properties of lansoprazole toward PHOSPHO1 and TNAP, implicated both in the mineralization process could boost the efficiency of lansoprazole to inhibit mineral formation.

\section{MATERIALS AND METHODS}

Isolation of matrix vesicles. MVs were isolated from 17-day-old chicken embryos (Balcerzak et al., 2007). They were stored in ice cold synthetic cartilage lymph (SCL) containing $2 \mathrm{mM} \mathrm{CaCl}$ and 1.42 $\mathrm{mM} \mathrm{NaH} \mathrm{PO}_{4}$ in addition to $100 \mathrm{mM} \mathrm{NaCl}, 1.83$ $\mathrm{mM} \mathrm{NaHCO}{ }_{3}, 12.70 \mathrm{mM} \mathrm{KCl}, 0.57 \mathrm{mM} \mathrm{MgCl} \cdot 6 \mathrm{H}_{2} \mathrm{O}$, $0.57 \mathrm{mM} \mathrm{Na} \mathrm{SO}_{4}, 63.50 \mathrm{mM}$ sucrose, $5.55 \mathrm{mM}$ D-glucose, 16.5 mM TES pH 7.4 (Wu et al., 1997). Protein concentration in the vesicles was determined by the method of Bradford (Bradford, 1976).

Isolation of tissue-nonspecific alkaline phosphatase by phosphatidylinositol-phospholipase $\mathrm{C}$ treatment. MVs were incubated in SCL medium containing $6 \mu \mathrm{M} \mathrm{ZnCl}_{2}, 20 \mathrm{mM} \mathrm{MgCl}$ and $1.5 \times 10^{-3}$ units phosphatidylinositol phospholipase C (PI-PLC) $/ \mu \mathrm{g}$ MVs proteins for $6 \mathrm{~h}$ at $37^{\circ} \mathrm{C}$ under gentle vortexing (Zhang et al., 2005). The supernatant and the pellet were separated by centrifugation at $100000 \times g$ for $30 \mathrm{~min}$. The supernatant containing tissue-nonspecific alkaline phosphatase was collected. For comparison, commercial tissue-nonspecific alkaline phosphatase from porcine kindey was purchassed from Sigma.
Fluorescence determination of phosphocholine hydrolysis. The fluorescence of resorufin induced by the reaction of 10-acetyl-3,7-dihydroxyphenoxazine (Amplex Red PLD Kit, Molecular Probes) and $\mathrm{H}_{2} \mathrm{O}_{2}$ produced by the oxidation of Chol to betaine was monitored at $585 \mathrm{~nm}$ after sample excitation at $571 \mathrm{~nm}$ on a F-4500 Hitachi Fluorescence Spectrophotometer. Slits for excitation and emission were set at 2.5 and $5 \mathrm{~nm}$, respectively. MVs $(20 \mu \mathrm{g}$ protein $/ \mathrm{ml}$ ) in $50 \mathrm{mM}$ Tris $/ \mathrm{HCl}, \mathrm{pH} 7.4,140 \mathrm{mM}$ $\mathrm{NaCl}$ without any additions or in the presence of inhibitors such as $1-5 \mathrm{mM}$ levamisole , $0.1 \mathrm{mM}$ vanadate or $1 \mathrm{mM}$ lansoprazole were mixed with $500 \mu \mathrm{l}$ of reaction buffer containing $50 \mu \mathrm{M}$ Amplex reagent, $1 \mathrm{U} / \mathrm{ml}$ of horseradish peroxidase (HRP) and $1 \mathrm{U} / \mathrm{ml}$ of choline oxidase from Alcaligenes sp. (Balcerzak et al., 2006).

Phosphomonoesterase activity assays. The phosphomonoesterase (PME) activity of TNAP was measured (at $420 \mathrm{~nm}$ ) with $10 \mathrm{mM} \mathrm{p}$-nitrophenyl phosphate ( $p$ NPP) as substrate (Engstrom, 1961 ) in the reaction solution containing $25 \mathrm{mM}$ piperazine and $25 \mathrm{mM}$ glycylglycine at $\mathrm{pH} 10.4$ and at $37^{\circ} \mathrm{C}$. One unit of the activity was defined as the amount of enzyme hydrolyzing $1 \mu \mathrm{mol}$ of substrate per min.

\section{RESULTS}

Lansoprazole inhibition of phosphocholine hydrolysis by tissue-nonspecific alkaline phosphatase

To determine PHOSPHO1 activity in MVs, addition of exogenous Pchol (a substrate for PHOSPHO1 as well as for other phosphomonesterase enzymes such as TNAP), we measured the hydrolysis of Pchol, using the fluorescence of resorufin. MVs $(20 \mu \mathrm{g}$ protein $/ \mathrm{mL})$ were able to hydrolyze completely within $20 \mathrm{~min}$ at $\mathrm{pH}$ 7.4, $1 \mu \mathrm{M}$ exogenous-Pchol by forming choline and $P_{i}$ (Fig. 1). Since PHOSPHO1 is a cytosolic enzyme entrapped inside MVs, this suggested either that phosphocholine was transported inside MVs and hydrolyzed inside by PHOSPHO1 and/or that phosphocholine was hydrolyzed by MV-phosphomonoesterase enzymes such as TNAP pointing to the extracellular side. Since MVs are enriched in GPI-anchored TNAP, we checked the phosphocholine hydrolysis by using TNAP inhibitors. Addition of TNAP inhibitor (either $5 \mathrm{mM}$ levamisole or $0.1 \mathrm{mM}$ vanadate) prevented almost completely the Pchol hydrolysis, indicating that TNAP was implicated in the hydrolysis of Pchol. Addition of $1 \mathrm{mM}$ lansoprazole, a PHOSPHO1 inhibitor (Roberts et al., 2007) inhibited partially the Pchol 


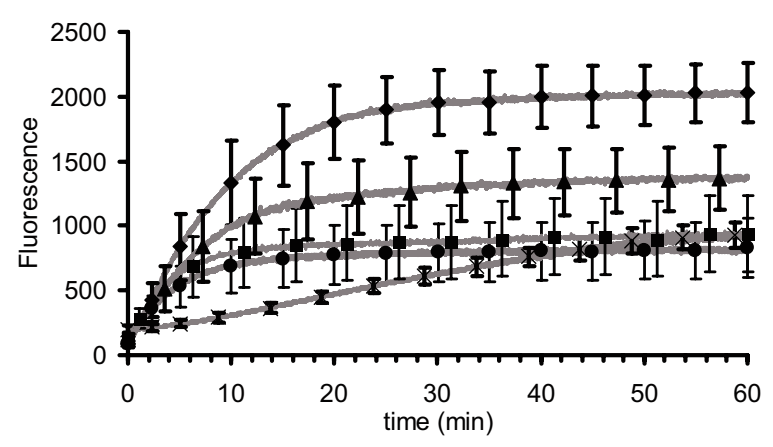

Figure 1. Pchosphocholine hydrolysis at $\mathrm{pH} 7.4$ by matrix vesicles.

MVs $(20 \mu \mathrm{g}$ protein $/ \mu \mathrm{L})$ in $50 \mathrm{mM}$ Tris/ $\mathrm{HCl}, \mathrm{pH} 7.4,140$ $\mathrm{mM} \mathrm{NaCl}$ at $25^{\circ} \mathrm{C}$ without any additions (-). MVs $(20 \mu \mathrm{g}$ protein $/ \mu \mathrm{L}$ ) in the presence of $1 \mu \mathrm{M}$ Pchol without any inhibitor $(\bullet)$ or with $5 \mathrm{mM}$ levamisole $(\boldsymbol{X})$, or with $0.1 \mathrm{mM}$ vanadate $(\boldsymbol{\square})$ or with $1 \mathrm{mM}$ lansoprazole $(\boldsymbol{\Delta})$. Values are the mean from three samples.

hydrolysis by MVs, suggesting that PHOSPHO1 was implicated in the Pchol hydrolysis and that the remaining hydrolysis activity was due to other phosphomonesterase enzymes. To confirm the origin of enzymatic inhibition by lansoprazole, TNAP was isolated from MVs after PI-PLC treatment and centrifugation. The released TNAP from MVs was in the supernatant, while the PI-PLC treated MVs without TNAP was pelleted down. We observed that $1 \mathrm{mM}$ lansoprazole moderately inhibited the Pchol hydrolysis by isolated TNAP in the supernatant (Fig. 2), while $0.1 \mathrm{mM}$ vanadate and $5 \mathrm{mM}$ levamisole (Fig. 2) completely inhibited its activity. Lansoprazole also inhibited the Pchol hydrolysis at $\mathrm{pH} 7.4$ (Fig. 3) as well as $p$ NPP hydrolysis at $\mathrm{pH} 10.4$ (Fig. 4) by commercial TNAP

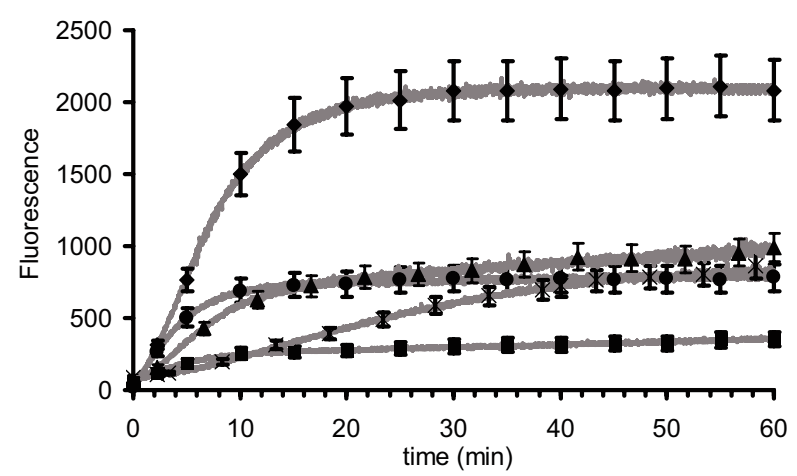

Figure 2. Pchosphocholine hydrolysis at $\mathrm{pH} 7.4$ by TNAP released from matrix vesicles after PI-PLC treatment. $20 \mu \mathrm{g}$ protein/mL TNAP extracted from MVs in $50 \mathrm{mM}$ Tris/ $\mathrm{HCl}, \mathrm{pH} 7.4,140 \mathrm{mM} \mathrm{NaCl}$ at $25^{\circ} \mathrm{C}$ : control (•). $20 \mu \mathrm{g}$ protein/mL TNAP extracted from MVs with $1 \mu \mathrm{M}$ Pchol $(\diamond)$; with $1 \mu \mathrm{M}$ Pchol and levamisole $5 \mathrm{mM}(\times)$; with 1 $\mu \mathrm{M}$ Pchol and vanadate $0.1 \mathrm{mM}(\boldsymbol{\square})$ or with $1 \mu \mathrm{M}$ Pchol and lansoprazole $1 \mathrm{mM}(\boldsymbol{\Delta})$. Values are the mean from three samples taken from all of the time points.

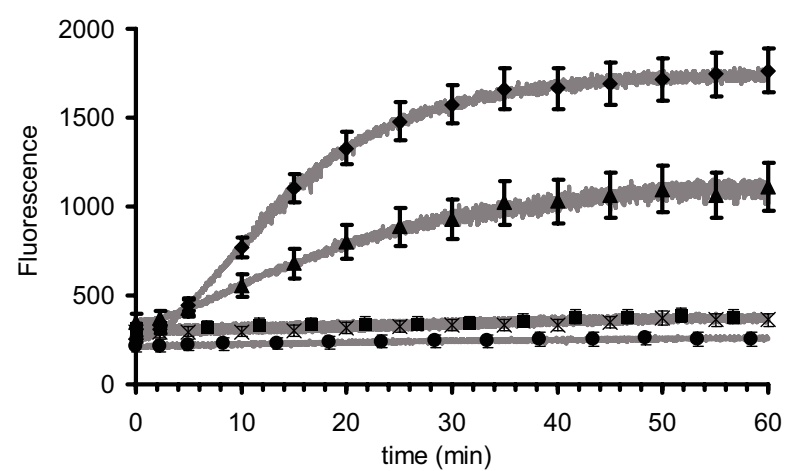

Figure 3. Pchosphocholine hydrolysis by commercial TNAP from porcine kidney.

Conditions: $50 \mathrm{mM}$ Tris/ $\mathrm{HCl}, \mathrm{pH} 7.4,140 \mathrm{mM} \mathrm{NaCl}, 25^{\circ} \mathrm{C}$, 0.25 TNAP unit $(\bullet) 0.25$ unit TNAP and Pchol $1 \mu \mathrm{M}(\bullet)$ and in the presence of inhibitors: levamisole $5 \mathrm{mM}(\mathbf{X})$, vanadate $0.1 \mathrm{mM}(\boldsymbol{\square})$ or lansoprazole $1 \mathrm{mM}(\boldsymbol{\Delta})$. Values are the mean from three samples taken from all of the time points.

from porcine kidney, confirming its inhibitory activity to TNAP.

\section{Determination of $K_{\mathrm{i}}$ value of lansoprazole}

The $p$ NPP-hydrolysis inhibition of lansoprazole on TNAP at $\mathrm{pH} 10.4$ was determined by using Lineweaver-Burk plots. Four distinct lansoprazole concentrations from $0,0.5,1$, and $1.5 \mathrm{mM}$ and $p$ NPP concentrations ranging from $15 \mathrm{mM}$ to 250 $\mathrm{mM}$ served to determine the kinetic parameters (Table 1). An apparent $K_{\mathrm{i}}$ value of $1.74 \pm 0.12 \mathrm{mM}$ was determined and our findings indicated that lansoprazole inhibited the hydrolysis by TNAP in an uncompetitive manner.

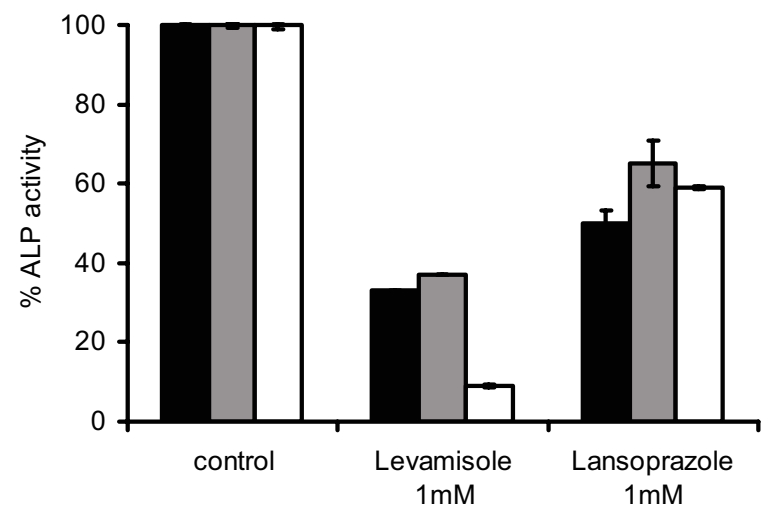

Figure 4. $p$ NPP hydrolysis by matrix-vesicle TNAP. Conditions: $25 \mathrm{mM}$ piperazine and $25 \mathrm{mM}$ glycylglycine at $\mathrm{pH} 10.4,37^{\circ} \mathrm{C}$. Matrix vesicles $20 \mu \mathrm{g}$ protein/mL (dark). TNAP from matrix vesicles after PI-PLC treatment $20 \mu \mathrm{g}$ protein/mL (grey) and commercial TNAP from porcine kidney 0.25 unit (white). As indicated in the figure, with or without inhibitors, $1 \mathrm{mM}$ levamisole or $1 \mathrm{mM}$ lansoprazole. Values are the mean from three samples. 
Table 1. Apparent $K_{\mathrm{i}}$ and $K_{\mathrm{m}}$ values for lansoprazole concentrations ranging from 0 to $1.5 \mathrm{mM}$, obtained from Lineweaver-Burk plot with porcine TNAP and $10 \mathrm{mM} p \mathrm{NPP} p \mathrm{pH}$ 10.4.

\begin{tabular}{lll}
\hline & Apparent $K_{\mathrm{m}}$ & $K_{\mathrm{i}}$ \\
\hline TNAP & $0.70 \pm 0.10 \mathrm{mM}$ & \\
TNAP + 500 $\mu$ M lansoprasole & $0.54 \pm 0.05 \mathrm{mM}$ & $1.83 \mathrm{mM}$ \\
TNAP + 1 mM lansoprasole & $0.43 \pm 0.11 \mathrm{mM}$ & $1.60 \mathrm{mM}$ \\
TNAP + 1.5 mM lansoprasole & $0.38 \pm 0.02 \mathrm{mM}$ & $1.78 \mathrm{mM}$ \\
\hline Mean & & $1.74 \pm 0.12 \mathrm{mM}$ \\
\hline
\end{tabular}

cifications (Anderson, 2007). MVs of affected cartilage in osteoarthritis increases TNAP activity as much as 30fold and induce HA deposition (Ali, 1985) indicating that TNAP (Narisawa et al., 2007; Sidique et al., 2009) could be a likely drug target, among other enzymes implicated in the mineral formation. Indeed, one likely source of $P_{i}$ in the extracellular matrix to sustain HA nucleation and growth is obtained through the activity of TNAP (either within cells or within MVs) (Regis-

\section{DISCUSSIONS}

In this work, we found that lansoprazole, a potent inhibitor of PHOSPHO1 (Roberts et al., 2006) inhibited the Pchol hydrolysis in an uncompetitive manner by TNAP within MVs or by isolated TNAP at $\mathrm{pH}$ 7.4. A $K_{\mathrm{i}}$ value of $1.74 \pm 0.12 \mathrm{mM}$ for the uncompetitive inhibition of $p \mathrm{NPP}$ at $\mathrm{pH} 10.4$ by alkaline phosphatase with lansoprazole was found while a $K_{\mathrm{i}}$ value of $28 \pm 9.21 \mu \mathrm{M}$ was obtained for lansoprazole inhibiting PHOSPHO1 (Roberts et al., 2006). Due to the fact that PHOSPHO1 is a cytosolic enzyme entrapped inside MVs, while TNAP active site is located toward the extracellular matrix, lansoprazole could inhibit not only PHOSPHO1 but also TNAP despite its relatively higher $K_{\mathrm{i}}$ value than that of PHOSPHO1. Although lansoprazole may not be the best therapeutical option for curing osteoarthritis diseases characterized by HA deposits, it may contribute as an adjunct therapy to cure osteoarthritis. This is especially true for patients being treated for gastroesophageal reflux disease with lansoprazole and having osteoarthritis. Lansoprazole, used for the treatment of gastroesophageal reflux disease, under acidic conditions undergoes to an acid catalyzed rearrangement to a cationic sulfenamide, forming disulfides with cysteines of the $\mathrm{H}^{+} / \mathrm{K}^{+}$-ATPase proton pump and inhibiting it. However, in the case of TNAP and PHOSPHO1, the inhibition of phosphomonoesterase activity can occur at $\mathrm{pH} 7.4$ and therefore the mode of action is different. The rationale to cure pathological calcification by targeting TNAP and PHOSPHO1 within MVs is supported by the fact that not only MVs appear to initiate skeletal mineralization, but MVs are also involved in a variety of pathological calcifications (Anderson 1983; 1988; 2007; Ali, 1985; Kirsch, 2007). Calcified diseases associated with osteoarthritis are correlated with the deposition of calcium pyrophosphate dihydrate (CPPD) crystals (25-55\% of the time) and/or of the deposition of basic calcium phosphate (BCP) crystals (35-70\% of the time) consisting of carbonate-substituted HA and octacalcium phosphate (Gordon et al., 1984; Carrol et al., 1991; Derfus et al., 2002; Nalbant et al., 2003). It has been proposed that MVs could be the target of a potential therapy for pathologic cal- ter et al., 1986; Balcerzak et al., 2003; Anderson et al., 2004) which can produce $P_{i}$ but can also hydrolyze $\mathrm{PP}_{\mathrm{i}}$, an inhibitor of $\mathrm{HA}$ formation (Register \& Wuthier, 1985). A complete inhibition of TNAP may decrease HA deposition; however, it will increase calcium pyrophosphate dihydrate (CPPD) deposition, since accumulation of $\mathrm{PP}_{\mathrm{i}}$ in the presence of $\mathrm{Ca}^{2+}$ leads to CPPD. Therefore, a partial inhibition of TNAP could be more effective than a complete inhibition to prevent calcified diseases. Levamisole, a known TNAP inhibitor, has been used for curing rheumatoid arthritis (McGill, 1976; Miller et al., 1980) suggesting that TNAP could serve as drug target for preventing HA deposition in cartilage.

\section{Acknowledgements}

Dr. Mélanie Délomenède was the recipient of a Postdoctoral scholarship from CNRS.

\section{REFERENCES}

Ali SY (1985) Apatite-type crystal deposition in arthritic cartilage. Scan Electron Microsc 4: 1555-1566.

Anderson HC (1983) Calcific diseases, A concept. Arch Pathol Lab Med 107: 341-348.

Anderson HC (1988) Mechanisms of pathological calcification. Rheum Dis Clin North Am 14: 303-319.

Anderson HC (2007) The role of matrix vesicles in physiological and pathological calcification. Curr Opin Orthop 18: $428-433$.

Anderson HC, Sipe JB, Hessle L, Dhanyamraju R, Atti E, Camacho NP (2004) Impaired calcification around matrix vesicles of growth plate and bone in alkaline phosphatase-deficient mice. Am J Pathol 164: 841-847.

Balcerzak M, Hamade E, Zhang L, Pikula S, Azzar G, Radisson J, Bandorowicz-Pikula J, Buchet R (2003) The roles of annexins and alkaline phosphatase in mineralization process. Acta Biochim Polon 50: 1019-1038.

Balcerzak M, Pikula S, Buchet R (2006) Phosphorylationdependent phospholipase $\mathrm{D}$ activity of matrix vesicles. FEBS Let 580 : 5676-5680.

Balcerzak M, Radisson J, Azzar G, Farlay D, Boivin G, Pikula S, Buchet R (2007) A comparative analysis of strategies for isolation of matrix vesicles. Anal Biochem 361: 176-182.

Bradford MM (1976) A rapid and sensitive method for the quantitation of microgram quantities of protein utiliz- 
ing the principle of protein-dye binding. Anal Biochem 72: 248-254.

Besancon M, Simon A, Sachs G, Shin JM (1997) Sites of reaction of the gastric $\mathrm{H}, \mathrm{K}-\mathrm{ATPase}$ with extracytoplasmic thiol reagents. J Biol Chem 272: 22438-22446.

Carroll GJ, Stuart RA, Armstrong JA, Breidahl BA, Laing BA (1991) Hydroxyapatite crystals are a frequent finding in osteoarthritis synovial fluid, but are not related to increased concentrations of keratan sulfate or interleukin 1 beta. J Rheumatol 18: 861-866.

Cyboron GW, Wuthier RE (1981) Purification and initial characterization of intrinsic membrane-bound alkaline phosphatase from chicken epiphyseal cartilage. J Biol Chem 256: 7262-7268.

Der G (2003) An overview of proton pump inhibitor. Gastroenterol Nurs 26: 182-190.

Derfus BA, Kurian JB, Butler JJ, Daft LJ, Carrera GF, Ryan LM, Rosenthal AK (2002) The high prevalence of pathologic calcium crystals in preoperatives knees. J Rheumatol 29: 570-574.

DeVault KR, Castel DO (1999) Updated guidelines for the diagnosis and treatment of gastroeosophageal reflux disease. The Practise Parameters Committee of the American College of Gastroenterology. Am J Gastroenterol 94: 1434-1442.

Einhorn TA, Gordon SL, Siegel SA, Hummel CF, Avitable MJ, Carty RP (1985) Matrix vesicle enzymes in human osteoarthritis. J Orthop Res 3: 160-169.

Engstrom L (1961) Studies on calf-intestinal alkaline phosphatase. I. Chromatographic purification, microheterogeneity and some other properties of the purified enzyme. Biochim Biophys Acta 52: 36-48.

Gordon GV, Villanueva T, Schumacher HR, Gohel V (1984) Autopsy study correlating degree of osteoarthritis, synovitis and evidence of articular calfication. J Rheumatol 11: 681-688.

Gremse DA (2001) Lansoprazole: pharmacokinetics, pharmacodynamics and clinical use. Expert Opin Pharmacother 2: 1663-1670.

Hsu HHT, Anderson HC (1996) Evidence of the presence of a specific ATPase responsible for ATP-initiated calcification by matrix vesicles isolated from cartilage and bone. J Biol Chem 271: 26383-26388.

Hsu HHT, Camacho NP, Anderson HC (1999) Further characterization of ATP-initiated calcification by matrix vesicles isolated from rachitic rat cartilage. Membrane perturbation by detergents and deposition of calcium pyrophosphate by rachitic matrix vesicles. Biochim Biophys Acta 1416: 320-332.

Kirsch T (2007) Physiological and pathological calcification: a complex multifactorial process. Curr Opin Orthop 18: 425-427.

Kivioja A, Linnosmaa I, Vehviläinen A, Vohlonen L (2004) Cost-minimization analysis of treatment of gastroesophageal reflux disease: implications of varying holding time on coclusions. Eur J Pharm Sci 21: 171-178.

McGill PE (1976) Levamisole in rheumatoid arthritis. Lancet 1: 149 .
Miller B, Demerieux P, Spinivasan R, Clemments P, Fan P, Levy J, Paulus HE (1980) Double-blind placebo-controlled cross-over evaluation of levamisole in rheumatoid arthritis. Arthritis Rheum 23: 172-182.

Nalbant S, Martinez JA, Kitumnuaypong T, Clayburne G, Sieck M, Schumacher Jr HR (2003) Synovial fluid features and their relations to osteoarthritis severity: new findings from sequential studies. Osteoarthritis Cartilage 11: 50-54.

Narisawa S, Harmey D, Yadav MC, O'Neill WC, Hoylaerts MF, Millán JL (2007) Novel inhibitors of alkaline phosphatase suppress vascular smooth cell calcification. J Bone Miner Res 22: 1700-1710.

Register TC, Wuthier RE (1985) Effect of pyrophosphate and two biphosphonate on ${ }^{45} \mathrm{Ca}$ and ${ }^{32} \mathrm{Pi}$ uptake and mineralization by matrix vesicle-enriched fractions and by hydroxyapatite. Bone 6: 307-312.

Register TC, McLean FM, Low MG, Wuthier RE (1986) Roles of alkaline phosphatase and labile internal mineral in matrix vesicle-mediated calcification. J Biol Chem 261: 9354-9360.

Roberts SJ, Stewart AJ, Sadler PJ, Farquharson C (2004) Human PHOSPHO1 displays high specific phosphoethanolamine and phosphocholine phosphatase activity. Biochem J 382: 59-65.

Roberts SSJ, Stewart AJ, Schmid R, Blindauer CA, Bond SR, Sadler PJ, Farquharson C (2005) Probing substrate specificities of human PHOSPHO1 and PHOSPHO2. Biochim Biophys Acta 1752: 73-82.

Roberts SJ, Stewart AJ, Seawright E, Davey E, Fleming MG, Farquharson C (2006) The presence of PHOSPHO1 in matrix vesicles and its developmental expression prior to skeletal mineralization. Bone 39: 1000-1007.

Roberts SJ, Narisawa S, Harmey D, Milan JL, Farquharson C (2007) Functional involvement of PHOSPHO1 in matrix vesicle-mediated skeletal mineralization. J Bone Miner Res 22: 617-627.

Shi S, Klotz U (2008) Proton pump inhibitors: an update of their clinical use and pharmacokinetics. Eur J Clin Pharmacol 64: 935-951.

Sidique S, Ardecky R, Su Y, Narisawa S, Brown B, Millan JL, Sergienko E, Cosford DP (2009) Design and synthesis of pyrazole derivatives as potent and selective inhibitors of tissue-nonspecific alkaline phosphatase (TNAP). Biorg Med Chem Let 1 19: 222-225.

Wu LN, Genge BR, Dunkelberger DG, LeGeros RZ, Concannon B, Wuthier R (1997) Physicochemical characterization of the nucleational core of matrix vesicles. J Biol Chem 272: 4404-4411.

Zhang L, Balcerzak M, Radisson J, Thouverey C, Pikula S, Azzar G, Buchet R (2005) Phosphodiesterase activity of alkaline phosphatase in ATP-initiated $\mathrm{Ca}^{2+}$ and phosphate deposition in isolated chicken matrix vesicles. $J$ Biol Chem 280: 37289-37296. 